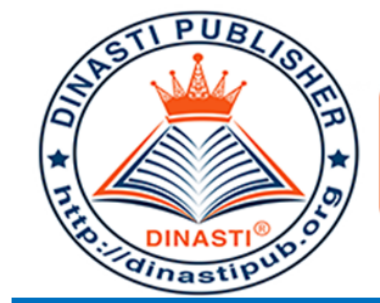

\title{
MANAGING DIVERSITY OF HUMAN RESOURCES AS AN EFFORT TO IMPROVE EMPLOYEE PERFORMANCE (CASE STUDY AT PT. LONTAR PAPYRUS PULP \& PAPER INDUSTRY)
}

\section{Said Almaududi}

Lecturer of Universitas Batanghari (UNBARI), Jambi Indonesia

ARTICLE INFORMATION
Received: 25 February 2020
Revised: 15 March 2020
Issued: 27 March 2020
Corresponding author:
Said Djamaludin
E-mail:
saidalmaududi@ gmail.com

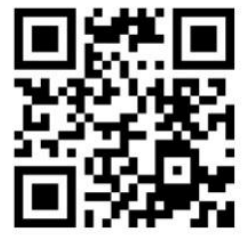

DOI: 10.38035/DIJEFA

\begin{abstract}
This study aims to analyze the effect of managing the diversity of human resources on the performance of employees of PT. Lontar Papyrus Pulp \& Paper Industry. The study population was all employees of PT. Lontar papyrus pulp \& paper industry, West Tanjung Jabung Regency, totaling 3,023 people. the size or number of samples in this study is determined based on the theory developed by Slovin with a value of $e=10 \%$, so that a sample of 97 people is obtained. The approach in this study uses a quantitative approach to the survey method and uses Partial Least Square (PLS) data analysis. But before the analysis, the outer model test is first performed through the validity and reliability test. Furthermore, the Inner Model test is carried out through the R-Square (Coefficient of determination) and F-Square (f2 effect size) tests. The results showed that the management of diversity in human resources affected the performance of the employees of PT. Lontar Papyrus Pulp \& Paper Industry. management of diversity in human resources affected the performance of the employees of PT. Lontar Papyrus Pulp \& Paper Industry.
\end{abstract}

Keyword: Managing Diversity, Human Resources, Performance

\section{INTRODUCTION}

Human resources is one of the most important aspects that most influences or plays an important role in achieving the company's vision, mission and goals. Management of human resources that is not good, will cause inconvenience of employees in work so that what is produced by employees on their work will be deemed less useful for the company, therefore a good management of human resources is needed. 
Human resources is one of the most important aspects that most influences or plays an important role in achieving the company's vision, mission and goals. Management of human resources that is not good, will cause inconvenience of employees in work so that what is produced by employees on their work will be deemed less useful for the company, therefore a good management of human resources is needed.

Similarly, PT. Lontar Papyrus Pulp \& Paper Industry (PT.LPPPI), as one of the manufacturing companies engaged in the production of pulp and tissue, human resource management is a matter of great concern by company management. Especially considering the diversity of human resources that exist in this company, which includes the main characteristics (primary characteristics), such as age, ethnicity, gender, ability, race, and including other characteristics (secondary characteristics) namely geography, work experience, income, religion, language, communication style, family status, work style, and education. Where these characteristics will certainly differ from one person to another, which in turn will affect the way they work and ultimately will affect the company or organization as a whole.

The development of human resources in this globalization era has given an indication of the importance of managing diversity in an organization. This is because if the diversity of human resources can be managed properly, it is expected to prevent conflict and maximize the advantages that can be obtained from the diversity of existing human resources.

The diversity of human resources today is a consequence of globalization, this should not be addressed as a threat to the company, but instead these conditions are seen as opportunities for companies to be able to operate more effectively. This is because the diversity of human resources will be a motivation and inspiration for companies to be able to deal with business changes that occur through creativity and more ability to see a problem from various points of view. Given that the diversity of human resources will greatly affect the management of a company's business, then it should be placed as one of the issues that is a top priority to be considered by the company's management (Hartini, T., 2012).

A number of literatures have mentioned the benefits that can be obtained by companies with good management regarding the diversity of human resources. Among them mentioned by Thomas and Ely in Hartini, T (2012), which states that by managing diversity of human resources properly, companies can increase their profitability, go beyond financial measures to achieve learning, enhance creativity, enhance organizational and individual growth, and increase the company's ability to make adjustments quickly and to make changes successfully.

Based on the explanation above, it is interesting to study further about the management of diversity of human resources in improving employee performance. To that end, the title raised in this research is "Managing Human Resource Diversity: An Effort to Improve Employee Performance (Case Study at PT. Lontar Papyrus Pulp \& Paper Industry)".

Based on the background and problems, the objectives to be achieved from this research are "Analyzing the effect of managing diversity of human resources on employee performance at PT. Lontar Papyrus Pulp \& Paper Industry." 


\section{LITERATURE REVIEW}

\section{Diversity Management}

Diversity can be interpreted literally as difference. The differences that are often discussed are differences in ethnicity, skin color, gender differences, and much more. Peters and Poutsma in Femi, B., and Prasetya, A (2017) suggest that diversity management is an inclusive approach that starts with recruiting or attracting different individuals into the company, then proposing and forming a broader understanding of different individuals with include various factors such as sexual orientation, skills and experience.

According to Bangun (2012) diversity management (diversity management) means taking steps to maximize the potential of diversity with differences in the characteristics of the members to achieve better performance. In practice, diversity management will involve each person with a different background in a predetermined value to achieve organizational goals.

The application of diversity management requires a multicultural paradigm that forms the basis of the organization. Cox in Hartini (2012) argues that an organization will become a multicultural organization only if it can give value to the cultural diversity that exists in it.

Diversity in organizations can be seen from various points of view. According to Williams and O'Reilly in Yuwono, S (2016), there are 2 main points of view in seeing diversity, namely social categorization perspective and information / decission-making perspective. The social categorization point of view sees the diversity in the unit indicating the existence of groups within it, which need to be seen not as a separate group but as a unit within the unit itself so that they are able to work together. The information / decision-making perspective states that diverse individuals will have different and unique perspectives, opinions, intelligence, knowledge, and skills, which will be very rich resources, so this diversity also needs to be managed appropriately in order to be optimal.

Van Knippenberg in Yuwono, S (2016) proposed a new perspective as an amalgamation of the two previous viewpoints, namely the categorization elaboration model (CEM). This model states that diverse groups are able to use the advantages of unique ways of thinking beyond homogeneous groups through the process of elaboration of information, which is defined as the exchange of information and perspectives, then individuals process the information and provide responses, which are then discussed and integrated for implementation.

According to Bangun (2012) there are five steps that can be used as measurements in managing the diversity of HR, namely: 1) Provide Strong Leadership; 2) Assess the Situation; 3) Provide Diversity Trainbing and Education; 4) Change Culture and Management System; and 5) Evaluate the Diversity Management Program.

\section{Performance}

Performance is the ability of employees to do certain skills. Employee performance is very necessary, because with this performance will be known how far their ability to carry out the tasks assigned to it (Sinambela, 2016). Mangkunegara (2012) performance is the result of quality and quantity of work achieved by an employee in carrying out their duties in accordance with the responsibilities given to him.

Meanwhile, according to Locke (2009) argues that historically, performance is defined as a series of task statements derived from job descriptions, then assessed to determine the extent to which they carry out these tasks. In addition, Gomes (2011) defines performance as a performance 
that results from work produced by employees or actual behaviors that are displayed in accordance with their role in the organization. According to Wibowo (2016) performance is about doing work and the results achieved from the work. Performance is about what is done and how to do it. Whereas according to Sedarmayanti (2014) performance is fulfilling or carrying out a votive obligation, the results of workers, organizational processes, proven concretely, perfecting responsibilities, can be measured, can be compared with predetermined standards.

According to Mangkunegara (2012), employee performance can be assessed from five indicators, namely: 1) Quality of work, which includes tidiness, accuracy, interrelation of work results without ignoring work volume; 2) Work quantity, including the large number of types of work performed at one time so that efficiency and effectiveness can be carried out in accordance with company goals; 3 ) Responsibilities, including responsibility for work results and facilities and infrastructure used and work behavior every day; 4) Cooperation, which includes the willingness of employees to participate with other employees vertically and horizontally both inside and outside the work so that the work will be better; and 5) Initiatives, which include initiatives from within members of the organization to do work and overcome problems at work without waiting for orders from superiors or showing responsibility in work that is an employee's obligations.

\section{Conceptual Framework}

Based on the problem formulation and literature review that has been described previously, the conceptual framework of the study refers to the relevant theories and previous research. As a comprehensive description of the interrelationships between variables used in the research model, below is presented a conceptual framework of the study. Where the research framework can be described in (figure 1) as follows:

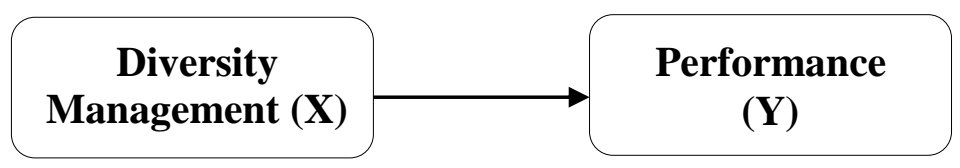

Figure 1. Conceptual Framework

Based on the framework that has been stated above, the research hypothesis is formulated as follows: "There is an influence of managing the diversity of human resources on performance."

\section{RESEARCH METHODS}

The study population was all employees of PT. Lontar papyrus pulp \& paper industry, West Tanjung Jabung Regency, totaling 3,023 people. the size or number of samples in this study is determined based on the theory developed by Slovin with a value of $e=10 \%$, so that a sample of 97 people is obtained.

Based on the research objectives, the type of research used is explanatory research. Explanatory research is research conducted to explain the causal relationships between research variables through hypothesis testing (Singarimbun and Effendi, 2012). The research approach used in this study is a quantitative approach. The process of quantitative approach starts from theory, which is revealed to be a research hypothesis using deductive logic accompanied by measurement 
and operationalization of variables. Furthermore, generalizations are made based on the results of statistical data so that conclusions can be drawn as research findings to answer the problems being faced.

The approach in this study uses a quantitative approach to the survey method and uses Partial Least Square (PLS) data analysis. Partial Least Square or abbreviated PLS is a component-based type of SEM with formative construct properties. Partial Least Square (PLS) is a powerful analytical technique because it can be applied at all data scales, does not need a lot of assumptions, and sample sizes do not have to be large. Although PLS is used to explain the presence or absence of relationships between latent variables (prediction), PLS can also be used to confirm theories. But before the analysis, the outer model test is first performed through the validity and reliability test. Furthermore, the Inner Model test is carried out through the R-Square (Coefficient of determination), F-Square and (f2 effect size) tests.

\section{FINDINGS AND DISCUSSION}

\section{Description of Research Variables}

Descriptive statistics used are mean (mean) values, values that often appear in the respondent's answer (mode), middle values (median), standard deviations (standard deviations) and sample variance. The results of descriptive statistics in the study using SPSS 21.0 tools are as follows:

Table 1. Descriptive Statistics of Research Variables

\begin{tabular}{lrrr}
\multicolumn{4}{c}{ Statistics } \\
\hline & X_Diversity_Management & Y_Performance \\
\hline N $\quad$ Valid & 97 & 97 \\
& Missing & 0 & 0 \\
Mean & 3,728 & 3,864 \\
Std. Error of Mean &, 0636 &, 0725 \\
Median & 3,800 & 4,100 \\
Mode & 3,8 & 4,5 \\
Std. Deviation &, 6261 &, 7145 \\
Variance &, 392 &, 510 \\
Range & 2,4 & 2,3 \\
Minimum & 2,4 & 2,4 \\
Maximum & 4,8 & 4,7 \\
Sum & 361,6 & 374,8 \\
\hline
\end{tabular}

Before assessing the criteria of the research variable, a score assessment criteria will be made first. With the highest number of scores is 5 , and the lowest number of scores is 1 . The classification of respondents' answers to the research variables can be described in terms of the score weights with a range of scores $5-1 / 5=0.8$, as follows:

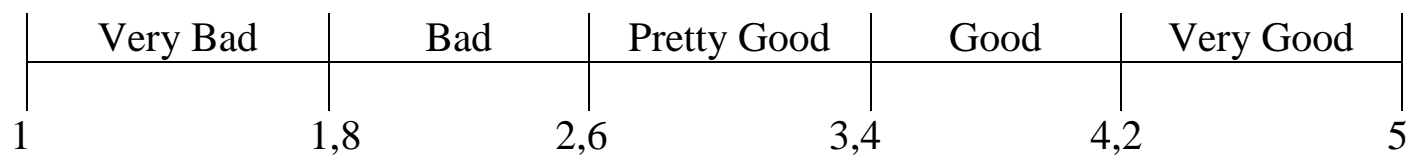

a. Description of Variable Diversity Management (X)

Descriptive results of diversity management variables as shown in Table 1 above obtained an average value of 3.728, including the range of 3.4 - 4.2 are in the Good criteria. This shows that the management of diversity management at PT. Lontar Papyrus Pulp \& Paper Industry has been going well. 


\section{b. Description of Performance Variables (Y)}

Descriptive results of performance variables as shown in Table 1 above obtained an average value of 3.864, including the range of 3.4 - 4.2 are in the Good criteria. Which explains that the performance of employees at PT. Papyrus Pulp \& Paper Industry has been going well.

\section{Reflective Model Measurement Results (Outer Model) Test Results}

The measurement model has the goal of representing the relationship between the construct and its corresponding indicator variables (commonly referred to as the outer model in PLS-SEM). The measurement model explains how constructs are measured and are reliable or valid and reliable by looking at convergent validity, discriminant validity, and construct reliability (Hair et al., 2017). The outer model image in SmartPLS is as follows:

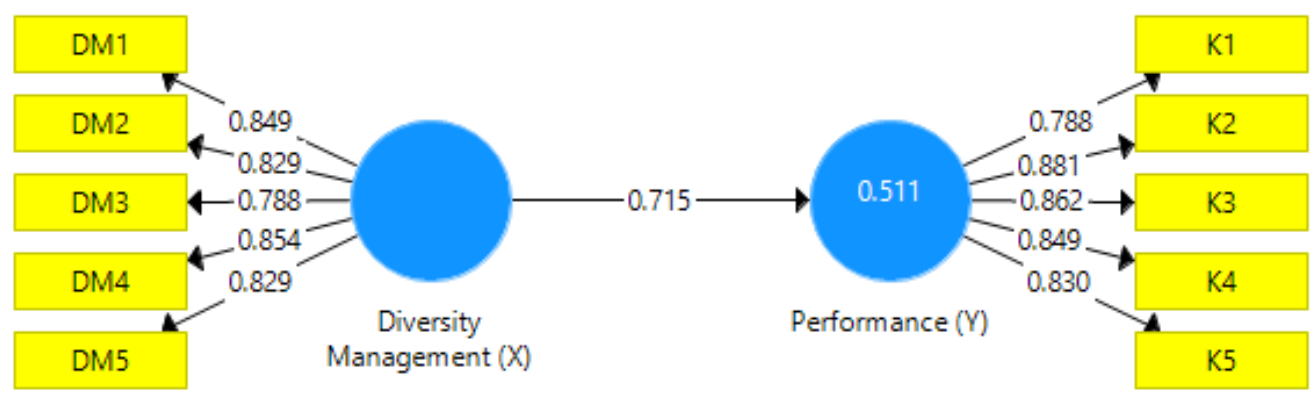

Figure 2. Outer Research Model on SmartPLS

Test the validity of the reflective construct is the extent to which the size of a contract should be highly correlated. Test the validity of the reflective construct with the reflective construct can be seen through the loading factor value for each indicator of the contract. The rule of thumb used is the loading factor standard value must be 0.7 or higher and the average extracted value (AVE) value must be greater than 0.5. High loading factor shows that the indicators contained in the construct have many similarities so that it has the same meaning in a construct (Hair et al., 2017). Here are the results of loading factors and AVE values for each indicator:

Table. 2. Test the Validity of Reflective Constructions

\begin{tabular}{lcccc}
\hline \multicolumn{1}{c}{ Variable } & Indicator & $\begin{array}{c}\text { Loading } \\
\text { Factor }\end{array}$ & AVE & Information \\
\hline \multirow{2}{*}{ Diversity } & DM1 & 0,849 & & Valid \\
Management (X) & DM2 & 0,829 & & Valid \\
& DM3 & 0,788 & 0,689 & Valid \\
& DM4 & 0,854 & & Valid \\
& DM5 & 0,829 & & Valid \\
P1 & 0,788 & & Valid \\
& P2 & 0,881 & & Valid \\
& P3 & 0,862 & 0,710 & Valid \\
& P4 & 0,849 & & Valid \\
& P5 & 0,830 & & Valid \\
\hline
\end{tabular}

Source: Output SmartPLS, 2020. 
In general, indicators with outer loading between $0.40-0.70$ should be removed from the scale when removing the indicator leads to an increase in the value of composite reliability and the value of average variance extracted (AVE). Whereas indicators with very low outer loading values (below 0.40) must be eliminated from construction (Hair et al, 2017). Because the outer loading is very far from 0.4 , and above the AVE value, it can be concluded that all indicators have met the rule of thumb. So there is no need to eliminate indicators, and re-estimate.

In addition to testing the validity, the test that must be performed on the outer model is to conduct a reliability test. The reliability test is carried out, because the construct must be reliable because in order for the construct to show the instrument's accuracy, consistency, and accuracy in measuring a phenomenon. The following results from the composite reliability values in the table below are as follows:

Table 3. Composite Reliability Value

\begin{tabular}{lcc}
\hline \multicolumn{1}{c}{ Variable } & $\begin{array}{c}\text { Composite } \\
\text { Reliability }\end{array}$ & Information \\
\hline Diversity Management (X) & 0,917 & Reliable \\
\hline Performance (Y) & 0,924 & Reliable \\
\hline
\end{tabular}

Source: Output SmartPLS, 2020.

Based on the results in the table above, it shows that the composite reliability value produced by all constructs is more than 0.7 with a minimum value of 0.921 which is indicated by the OCB variable. Therefore, it can be concluded that all constructs in this study are reliable or meet the reliability test.

\section{Structural Model Test Results (Inner Model)}

When the measurement model (outer model) has stated good results, the next step in evaluating the results of PLS-SEM is to assess the structural model (inner model). The structural model is analyzed, which is an attempt to find evidence that supports the theoretical model (the theoretical relationship between exogenous constructs and endogenous constructs) (Ghozali, I., 2015).

\section{a. R-Square Value (Coefficient of determination)}

R-square values are used to indicate the extent to which exogenous constructs explain the endogenous constructs. To evaluate the structural model that is the R-square value which shows the predictive power of the model. The rule of thumb used is $0.75,0.50$, and 0.25 showing that the model is strong, moderate, and weak. (Hair et al, 2017). The results of the R-square values can be seen in the table below as follows:

Table 4. R-Square Value

\begin{tabular}{lrr}
\hline Variable & R Square & R Square Adjusted \\
\hline Performance (Y) & 0,511 & 0,506 \\
\hline
\end{tabular}

Source: Output SmartPLS, 2020.

Based on the results of data processing in the table above, it shows that the Performance variable has an R-square value of 0.511 which means that the performance variable can be explained by the diversity management construct with a percentage of $51.1 \%$. Then, it can be 
concluded that the structural model (inner model) test results of the performance variables are included in the "moderate" model category.

\section{b. F-Square Value $\left(f^{2}\right.$ Effect Size $)$}

The F-square is calculated to measure the importance of changing the R-square value when a particular construct is removed from the model to evaluate whether the construct that is removed has a substantive impact on endogenous structures. The rule of thumb to assess the f-square value is $0.02,0.15$, and 0.35 , which indicates that the effect value is small, medium and large, and the size of the effect with a value less than 0.02 indicates that the variable has no effect (Hair et al, 2017). The results of the F-square values can be seen in the table below as follows:

Table 5. F-Square Value

\begin{tabular}{lrr}
\hline Variables & Diversity Management $(\mathbf{X})$ & Performance (Y) \\
\hline Diversity Management $(\mathbf{X})$ & & $\mathbf{0 , 5 4 7}$ \\
\hline Performance (Y) & & \\
Source: SmartPLS output, 2020. &
\end{tabular}

Based on the above table, the value of diversity management on employee performance is obtained, amounting to 0.547 or $54.7 \%$ (large). This explains that diversity management contributes greatly to employee performance. This means that the better management of human resources in the company, the more it will improve the performance of its employees.

\section{Hypothesis Testing Results}

The next test is to see the significance that represents the hypothetical relationship between constructs or see the influence between variables on the path coefficients using the bootsrapping procedure. Next is the output bootsrapping to see the amount of the T-statistic value.

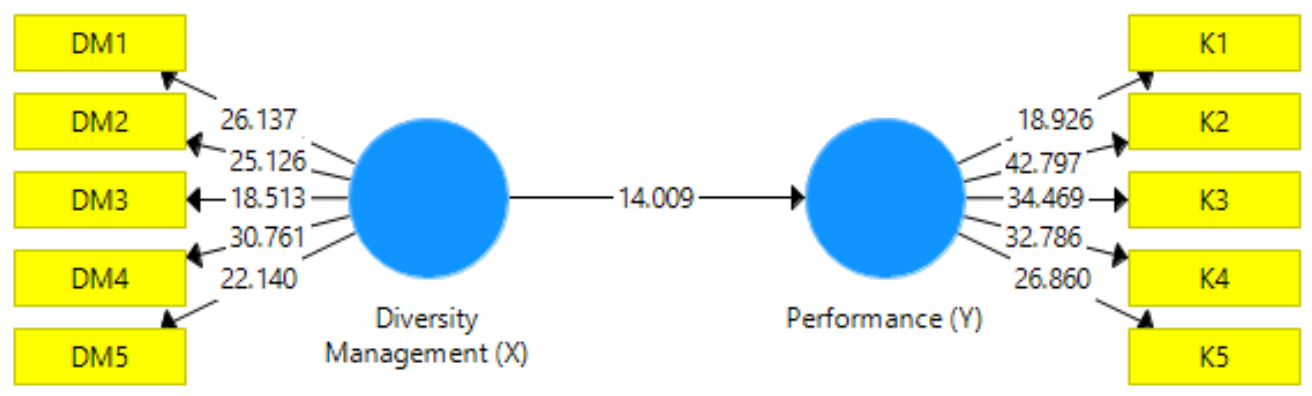

Figure 3. The Model of Construction Research Relationship with Bootstrapping Method

\section{Direct Effect}

Direct influence analysis is useful for testing the hypothesis of the direct effect of an influential variable (exogenous) on the variable affected (endogenous). The results of data processing are presented in the table below as follows:

Table 6. Path Coefficients Results

\begin{tabular}{ccccc}
\hline Hipothesys & $\begin{array}{c}\text { Path } \\
\text { Coefficient }\end{array}$ & T-Statistics & P Value & Information \\
\hline H1 : X -> Y & 0,715 & 14,009 & 0,000 & Accept \\
\hline Source: SmartPLS output, 2020. & & &
\end{tabular}


The path coefficients test results in the above table can be interpreted by looking at the original sample values to determine the relationship between variables. Meanwhile, to see the level of significance of the effect of the relationship between variables is by looking at $\mathrm{T}$ Statistics. Testing the hypothesis in this study using a significance level (significance level) of 5\% (two tailed) and a level of confidence (confidence level) of $95 \%$ so that the t-table is 1.9853 , if the value of $\mathrm{T}$ statistics> t-table then the results are significant (Ghozali, 2015).

Based on data from the test results in the table above obtained path coefficient of 0.715 with a $\mathrm{t}$-statistic value of 14.009 . These results indicate that diversity management variables significantly influence employee performance. Then it can be stated that hypothesis 1 (H1) is accepted. The results of this study support research conducted by Martanti, S.H (2018), Susilowati, Y (2013), and Pramuliawardani, W (2014) who stated that diversity management influences performance.

The development of human resources in this globalization era has given an indication of the importance of managing diversity in an organization. This is because if the diversity of human resources can be managed properly, it is expected to prevent conflict and maximize the advantages that can be obtained from the diversity of existing human resources.

A number of literatures have mentioned the benefits that can be obtained by companies with good management regarding the diversity of human resources. Among them mentioned by Thomas and Ely in Hartini, T (2012), which states that by managing diversity of human resources properly, companies can increase their profitability, go beyond financial measures to achieve learning, enhance creativity, enhance organizational and individual growth, and increase the company's ability to make adjustments quickly and to make changes successfully.

\section{CONSLUSSION AND SUGGESTION}

\section{Conclussion}

Based on the results and discussion, the conclusion of this study is that there is the effect of diversification management on the performance of the employees of PT. Lontar Papyrus Pulp \& Paper Industry. This indicates that if the company can manage the diversity of human resources well, then the company will be able to prevent conflict and maximize the advantages that can be obtained from the diversity of existing human resources.

\section{Suggestion}

Based on the results of the conclusions and the previous discussion of things in improving the performance of employees of PT. Lontar Papyrus Pulp \& Paper Industry can be submitted suggestions that might be useful as follows:

1) In an effort to improve the performance of employees of PT. Lontar Papyrus Pulp \& Paper Industry, management needs to improve the management of diversity of human resources better so that companies can prevent conflict and maximize the advantages that can be obtained from the diversity of existing human resources.

2) Considering that this research still has shortcomings, then the next researcher can conduct further research on other companies and use a larger sample than the sample that the researchers did in this study.

3) The next researcher can consider using other variables in order to improve employee performance, for example environmental variables, career development variables, leadership variables, or other variables that can support improving employee performance. 


\section{REFERENCE}

Bangun, W. 2012. Manajemen Sumber Daya Manusia. Erlangga: Jakarta.

Femi, B., dan Prasetya, A. 2017. Penerapan Diversity Manajement Dalam Rangka Meraih Competitive Advantage (Studi pada PT Petrokimia Gresik. Jurnal Administrasi Bisnis (JAB), Vol. 50, No. 5.

Ghozali, Imam. 2015. Structural Equation Modeling: Teori, Konsep dan Aplikasi dengan Program Lisrel 9.10, Edisi 4. Semarang: Badan Penerbit UNDIP.

Gomes, F. C. 2011. Manajemen Sumber Daya Manusia. Penerbit Andi: Yogyakarta.

Hartini, T. 2012. Mengelola Keragaman Sumberdaya Manusia: Suatu Upaya Mengoptimalkan Kinerja Organisasi. Forum Bisnis dan Kewirausahaan, Jurnal Ilmiah STIE MDP, Vol. 1, No. 2.

Hair, J.F., Tomas, G.M.H., Ringle, Christian M., dan Marko Sarstedt 2017. A Primer Partial Least Squares Structural Equation Modeling. SAGE Publication.Ltd: Los Angeles.

Locke, E. 2009. Handbook of principles of Organizational Behavior. Antony Rowe Ltd: Chippenham Wiltshire.

Mangkunegara A.P. 2012. Manajemen Sumber Daya Manusia Perusahaan. PT. Remaja Rosdakarya: Bandung.

Martanti, S.H. 2018. Pengaruh Keberagaman Tenaga Kerja Terhadap Kinerja Karyawan Yang Dimoderasi Oleh Lingkungan Kerja (Universitas Kristen Petra Surabaya). Jurnla Ilmu Manajemen, Volume 6, Nomor 4.

Pramuliawardani, W. 2014. Pengaruh Keragaman Tenaga Kerja Terhadap Kinerja Karyawan Bagian Pemeliharaan PT, Dian Swastatika Sentosa, Tangerang Selatan. Skripsi Universitas Pendidikan Indonesia.

Sedarmayanti. 2014. Manajemen sumber daya manusia. Bandung: Mandar Maju.

Sinambela, Lijan Poltak. 2016. Manajemen Sumber Daya Manusia Membangun Tim Kerja yang Solid untuk Meningkatkan Kinerja. Bumi Aksara: Jakarta.

Singarimbun, M \& Effendi, S. 2007. Metode Penelitian Survey. LP3ES: Jakarta.

Susilowati, Y. 2013. Pengaruh Aspek Pengelolaan Sumber Daya Manusia Terhadap Peningkatan Kinerja Organisasi di Industri Otomotif di Indonesia. Jurnal Manajemen Teknologi, Volume 12, Nomor 1.

Wibowo. 2016. Manajemen Kinerja. Edisi Kelima. PT. Raja Grafindo Persadara: Jakarta.

Yuwono, S. 2016. Keragaman Dumberdaya Insani Sebagai Potensi Meningkatkan Kesejahteraan Karyawan. Seminar Asean $2^{\text {nd }}$ Psychology \& Humanity. 